\title{
Globalisation, Welfare Models and Social Expenditure in OECD Countries
}

\author{
Marcelo Santos $^{1}$ (D) $\cdot$ Marta Simões $^{1}$ (i)
}

Accepted: 9 November 2021 / Published online: 20 November 2021

(c) The Author(s), under exclusive licence to Springer Science+Business Media, LLC, part of Springer Nature 2021

\begin{abstract}
What difference do welfare models make for how globalisation in its different manifestations influences the composition of social expenditure? Using data for 36 Organisation for Economic Co-operation and Development (OECD) countries over the period 1990-2018 we examine whether and how different welfare state models influence the impact of the economic, social and political dimensions of globalisation on ten different social expenditure programs. The results indicate that the influence of globalisation (overall and each separate dimension) on different components of social spending varies across welfare models in intensity but in most cases presents a positive sign. We find a more intense positive reaction in the Nordic model for e.g. active labour market policies and housing expenditures, while the reactions of health and education spending are not context specific. Survivors pensions, incapacity related and unemployment benefits and other social policy areas respond to factors other than globalisation. These findings may have important consequences for cross-country convergence in standards of living between different welfare state regimes, as each dimension of globalisation proceeds at different paces. Previous literature also shows that changes in the composition of social expenditure result in different short and long run economic outcomes.
\end{abstract}

Keywords Welfare state models · Globalisation - Social expenditure - OECD · GMM

JEL Classification F68 $\cdot \mathrm{H} 19 \cdot \mathrm{H} 53 \cdot \mathrm{I} 38 \cdot \mathrm{P} 50$

Marta Simões

mcsimoes@fe.uc.pt

1 Univ Coimbra, CeBER, Faculty of Economics, Av Dias da Silva 165, Coimbra 3004-512, Portugal 


\section{Introduction}

A decades-long challenge for economics and political science research, among others, is to determine whether globalisation influences social expenditure. This is an important component of fiscal policy with the potential to influence economic activity, Crociata et al. (2020); Schuknecht and Zemanek (2021); Afonso and Jalles (2014); Furceri and Zdzienicka (2012). There are several competing theories on this nexus. Some predict a positive sign, others a negative sign, but there are also theories that pose that globalisation is irrelevant for the dynamics of social expenditure; the evidence is also not conclusive, Rodrik (1998); Schulze and Ursprung (1999); Koster (2009); Potrafke (2015); Heimberger (2021); Haelg et al. (2020). On the theoretical front, the efficiency hypothesis suggests that higher levels of globalisation result in less social expenditure in order to enhance international competitiveness by decreasing the tax burden. The former limits the capacity of countries to finance the respective welfare state. According to the compensation hypothesis, on the contrary, globalisation is expected to increase social expenditure as voters demand for more state intervention that promotes welfare for all. Governments should provide safety nets, through increased social expenditure, to those who are negatively affected by globalisation. It can also be the case that no link exists as the development of the welfare state responds to other attributes rather than to globalisation. Those include e.g. demography, historical arrangements or institutions. On the empirical front, the evidence produced to this date has not settled the issue on the sign or existence of a link between globalisation and social expenditure, Anderson and Obeng (2021); Heimberger (2021); Haelg et al. (2020).

The aim of this paper is threefold: i) investigate whether the relationship between globalisation and social expenditure differs for economic vs. political vs. social globalisation; ii) assess if the former nexus is welfare program-specific; and iii) examine whether the welfare state model adopted exerts an overarching influence in shaping the former relationships. Addressing these issues is particularly relevant at a time when globalisation is gaining new attention after the Covid19 outbreak and the rise in populism and nationalism, Enderwick and Buckley (2020); Bergh and Kärnä (2020). In the past, growing globalisation has raised concerns about its economic and social consequences namely through its impact on social policy. The overall impact of globalisation on social expenditure can also hide different signed effects on the variegated components of social spending that might cancel out in the aggregate. However, little is known about the link between different types of globalisation, the composition of social expenditure and the mediating role of welfare state regimes. This role has not been well documented and needs to be more systematically studied. We consider the mediating role of welfare state regimes on the relationship between globalisation and social expenditure during 1990-2018 for 36 OECD countries. We add to the literature, Kim and Zurlo (2009); Leibrecht et al. (2011); Onaran and Boesch (2014); Yay and Aksoy (2018) by exploring the differences in globalisation impacts across welfare regimes disentangling the influence of economic, social and political globalisation on ten different social policy areas defined according to the type of 
program considered in the OECD Social Expenditure (SOCX) database, OECD (2019), plus education. Since the understanding of the causal effect of globalisation on social expenditure is still limited we deal with the endogeneity of globalisation through instrumental variables techniques. In particular, we exploit exogenous variation in neighbouring countries levels of globalisation as instrumental variables in the context of the system generalized method of moments (GMM) estimation procedure. These features have not been investigated together in the existing studies on the importance of welfare state regimes for the link between globalisation and social expenditure. We hope to identify patterns relevant to inform social policy decisions in OECD countries and possibly in other countries too.

This paper is structured into four further sections. Section 2 locates within the relevant literature the welfare state regimes considered in the empirical analysis and reviews its relevance for the effects of globalisation on social expenditure. Section 3 presents the estimation methodology and the data used, and Sect. 4 reports and discusses the results. Section 5 concludes.

\section{Welfare State Regimes and the Social Spending Impacts of Globalisation: Classification and Literature Overview}

The welfare state, as defined for instance by Weir (2001) is “(...) a state that is committed to providing basic economic security for its citizens by protecting them from market risks associated with old age, unemployment, accidents, and sickness." But different welfare states models coexist, distinguishable in their historical development, structure and reach (accessibility, coverage, generosity, etc.), among other features. The most cited and often used classification of welfare state models is that proposed by Esping-Andersen (1990). The author distinguishes between three types of welfare states based on a historical analysis of 18 affluent OECD countries: social democratic (mostly in the Nordic countries); conservative or corporatist (applies mostly to continental Europe); and liberal (associated with Anglo-Saxon countries). The former taxonomy results from different degrees of welfare intervention by the state. The first is considered the most interventionist model, guaranteeing universal and more generous benefits. The conservative-corporatist model is less generous in comparison and relies mostly on social contributions. In the liberal regime the state provides even less benefits since the market is expected to act as a co-provider, Kammer et al. (2012).

Given the rather limited number of countries analysed by Esping-Andersen (1990), more recent taxonomies identify also a Southern European/Mediterranean welfare model (Italy, Greece, Portugal and Spain); an East Asian model (Japan, South Korea, Taiwan and Singapore); and a Central and Eastern European/transition countries model, Ferrera (1996); Goodman and Peng (1996); Wagener (2002); Hay and Wincott (2012); Kammer et al. (2012). The Southern European model groups the four Mediterranean countries that are similar in terms for instance of persistent labour market segmentation while the family plays a fundamental ancillary role in social protection. Still the former countries recorded some convergence in 
social spending levels to the Northern European and Conservative welfare models, Karamessini (2008). In the CEEC model the level of trust, the level of social programs and the social situation were initially (post-communist influence) lower than in the other Western European countries. This resulted in different options regarding welfare provision in terms of the public/private mix, Potůček (2008). According to Aspalter (2006), p.297 "A major attribute of the East Asian welfare model is its clear focus on productive investment in social and in particular human capital development, such as a commitment in education, healthcare, housing, work experience and training. (...) and a moderate commitment of the state to social security provision and welfare."

We divide our sample of 36 OECD countries across six welfare regimes based on the recent works of Tridico and Paternesi Meloni (2018) and Hein et al. (2021). The authors incorporate extensions of the Esping-Andersen's (1990) taxonomy stemming from Hay and Wincott (2012). They group countries in different welfare models by combining public social spending and redistributive policies data with socio-economic indicators. Their focus is on four specific indicators: trade union density; employment protection legislation; public social spending (as a share of GDP); and redistribution effectiveness. Table 4 in Hein et al. (2021) compares their five welfare regimes according to the four indicators. Besides the five welfare models in which Hein et al. (2021) divide their sample of 30 OECD countries, similar to Tridico and Paternesi Meloni (2018), that investigate 34 OECD countries, we consider a residual category of other welfare models. To be more specific, we divide our sample according to the following six welfare state models: 1) Social democratic or Nordic; 2) AngloSaxon/Liberal, 3) Continental European /Conservative/Corporative, 4) Southern European or Mediterranean, 5) the Central and Eastern European (CEEC) and 6) Others. Table 1 contains the country classification by welfare model in our sample of 36 OECD countries.

Figure 1 contains data on average total public social expenditure as a percentage of GDP across the six welfare state regimes over the period 1990-2018. Social democratic and conservative/corporative regimes start the period with higher shares

Table 1 Country classification by welfare model (36 OECD countries)

\begin{tabular}{llllll}
\hline $\begin{array}{l}\text { Social-democratic/ } \\
\text { Nordic }\end{array}$ & $\begin{array}{l}\text { Continental/ } \\
\text { Corporative/ } \\
\text { Conservative }\end{array}$ & $\begin{array}{l}\text { Anglo- } \\
\text { Saxon/ } \\
\text { Liberal }\end{array}$ & $\begin{array}{l}\text { Mediterranean/ } \\
\text { Southern } \\
\text { European }\end{array}$ & $\begin{array}{l}\text { Central \& Eastern } \\
\text { European }\end{array}$ & Others \\
\hline Denmark & Austria & Australia & Greece & Czech Republic & Chile \\
Finland & Belgium & Canada & Italy & Estonia & Israel Mexico \\
Iceland & France & Ireland & Portugal & Hungary & Turkey \\
Norway & Germany & New Zealand & Spain & Latvia & \\
Sweden & Japan & United & & Lithuania & \\
& Korea & Kingdom & & Slovak Republic & \\
& Luxembourg & United & & Slovenia & \\
& Netherlands & States & & & \\
& Switzerland & & & & \\
\end{tabular}

Source: based on Tridico and Paternesi Meloni (2018), Table I and Hein et al. (2021), Table 3. 


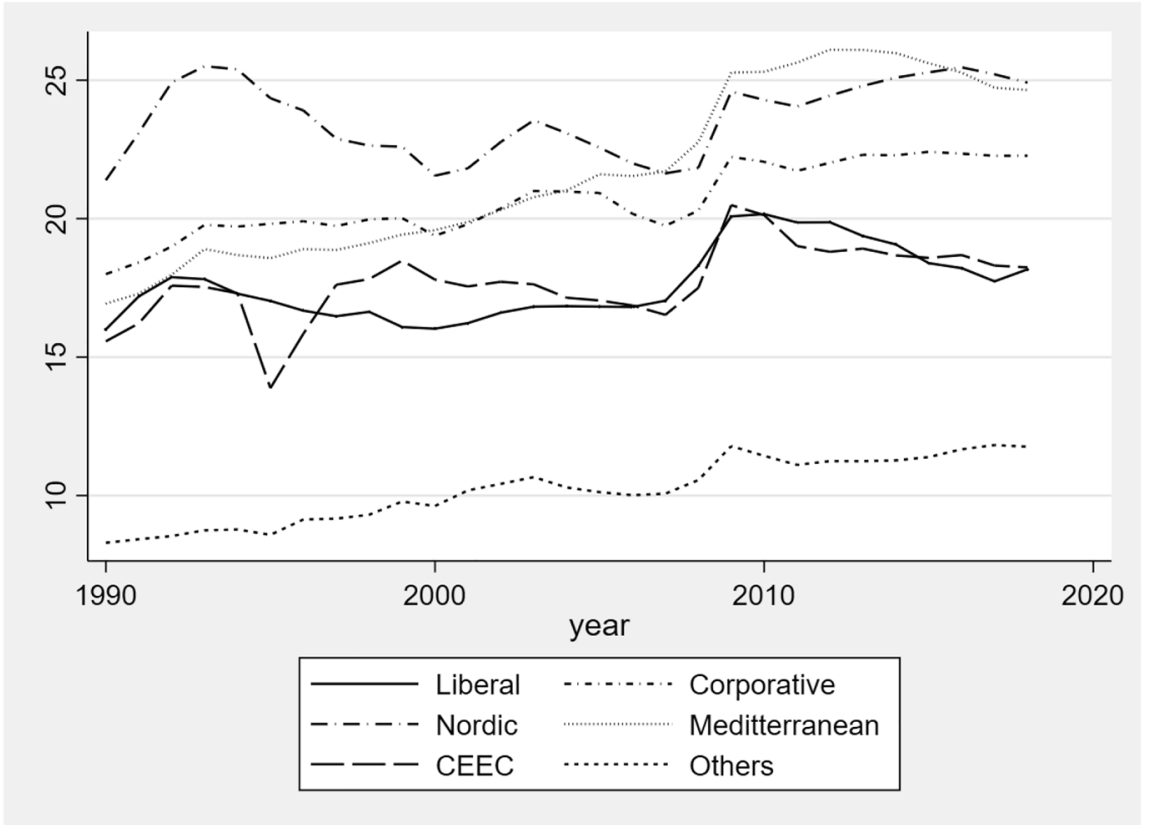

Source: own elaboration

Fig. 1 Total public social expenditure (\% GDP) by welfare state regime, 1990-2018

of social spending, about $21 \%$ and $18 \%$, respectively. They are followed at some distance by Mediterranean (about 17\%) and Liberal (about 16\%) regimes, while Others start at very low levels (about 8\%), and CEEC stand at about 10\%. Over the period, the Mediterranean regime converges and even surpasses (probably due to the rise in unemployment associated with the Great Recession) the Nordic (25\% in 2018) and conservative regimes (about 23\%), that seem to maintain the distance to each other. The Liberal and CEEC regimes show very similar numbers (about 19\% in 2018) and behaviour (except for the earlier part of the period under analysis, when CEEC start from a position closer to that of the regime Others). Their shares are relatively low when compared to the former three regimes and remain basically the same. The Others regime converges slightly to the higher shares of the remaining five regimes, but is still far from catching up (about $12 \%$ in 2018).

There is by now a rich empirical literature on the effects of globalisation on social expenditure, Rodrik (1998); Koster (2009); Anderson and Obeng (2021); Heimberger (2021). However, empirical studies that focus on the mediating role of welfare regimes (based on some adaptation of the previous welfare models taxonomies) on the relationship between globalisation and social expenditure are scarce. Table 2 contains a bird's eye view of these studies that frame our analysis. To the best of our knowledge these are limited to Kim and Zurlo (2009); Leibrecht et al. (2011); Onaran and Boesch (2014) and Yay and Aksoy (2018). Our work belongs to this strand of literature. 


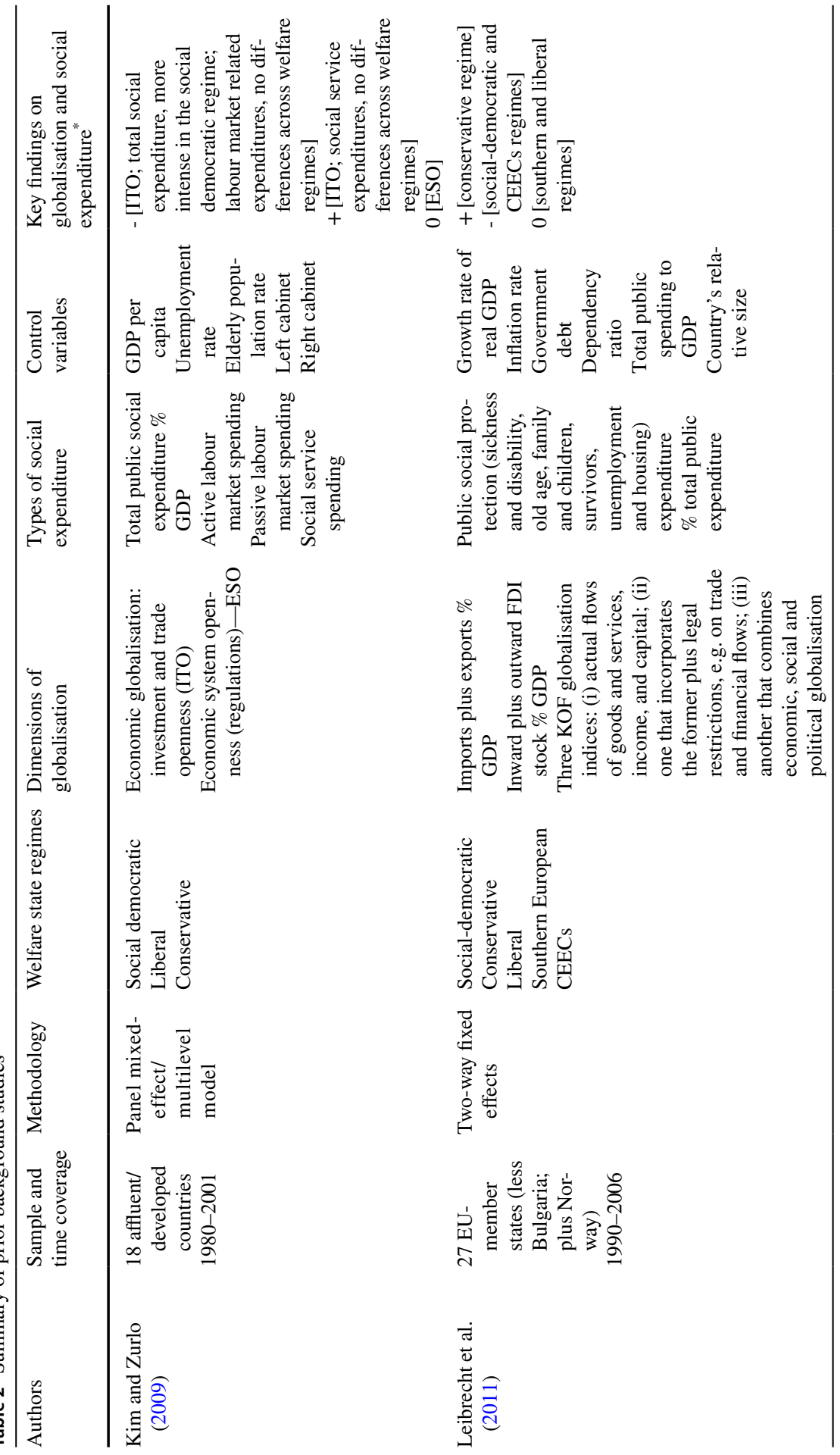




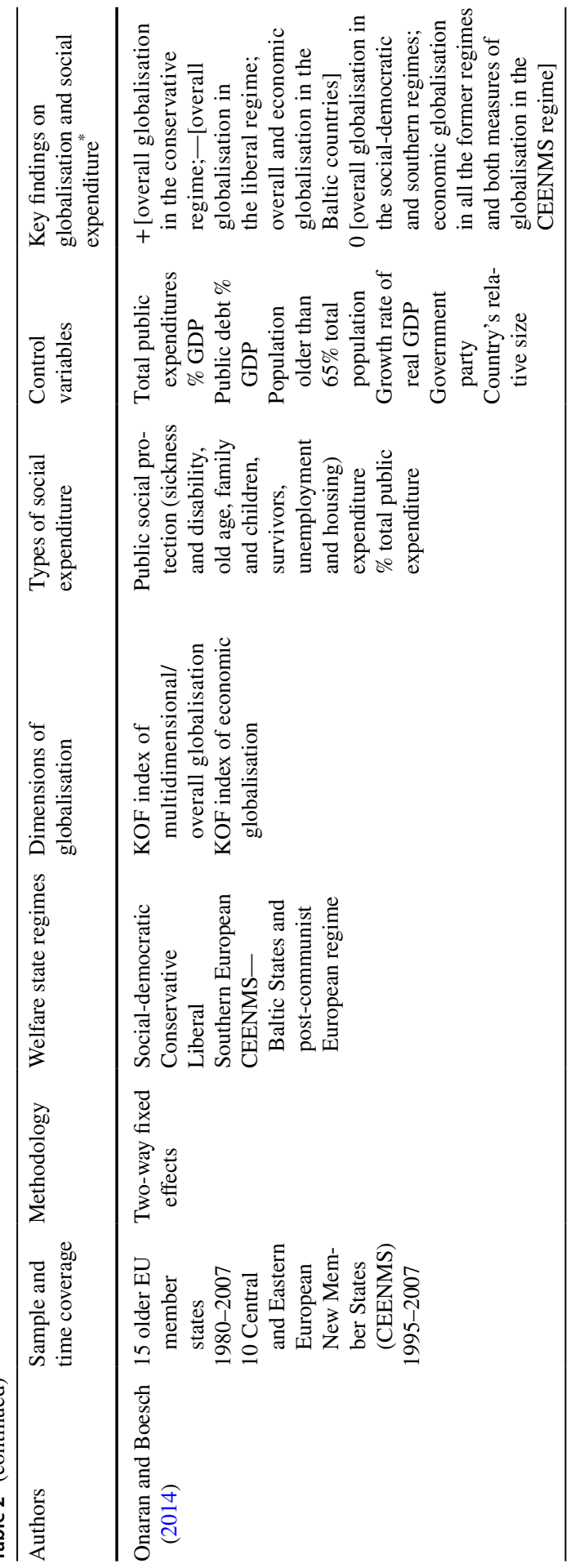




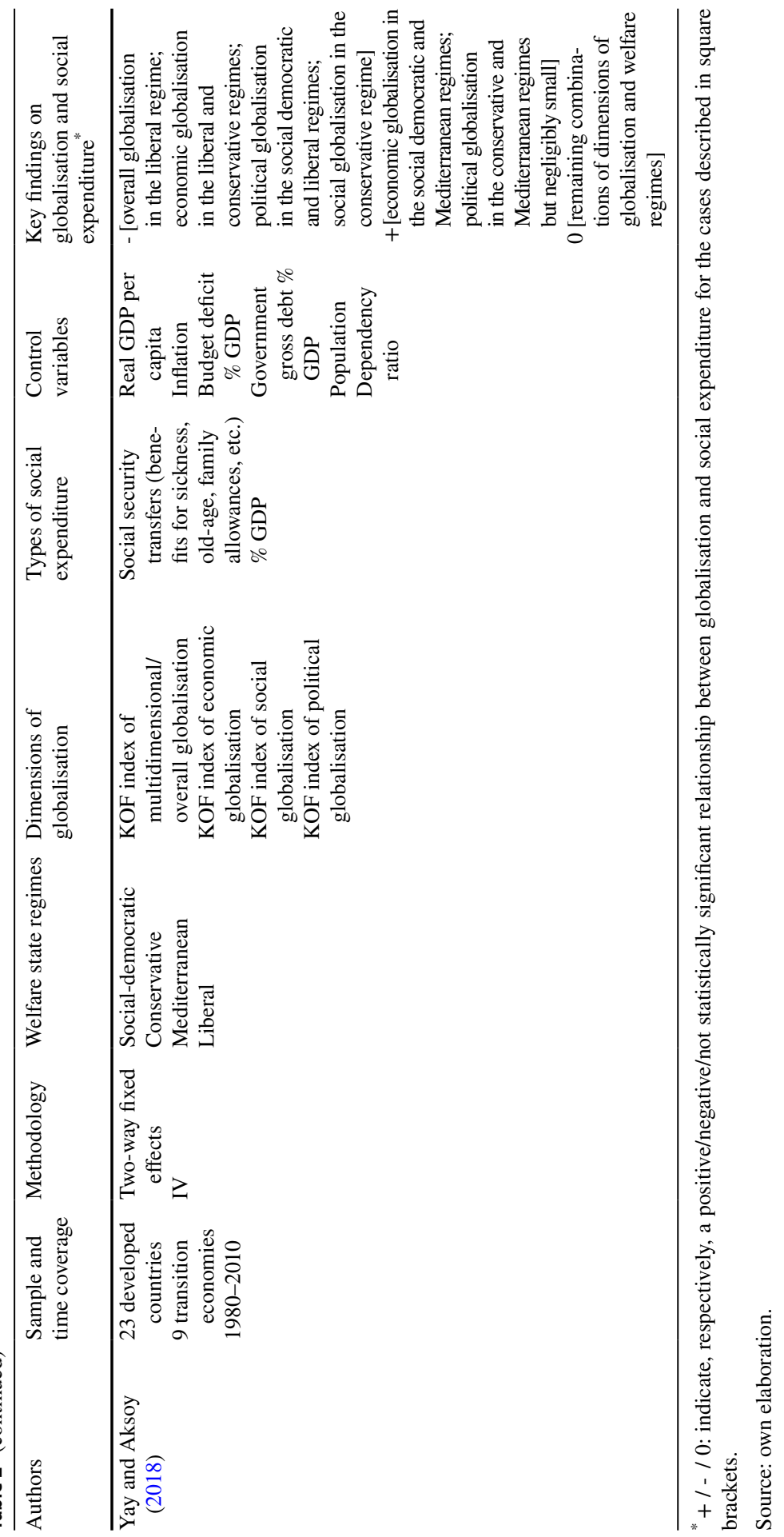


Countries are characterized by different types of welfare states belonging to different regimes. This entails a risk, when analysing samples of countries. It might even out the impact of globalisation on social expenditure of individual countries or groups of countries. According to Onaran et al. (2012), p. 881 "Different welfare states create different expectations and dependency relations among the citizens, which cannot be changed quickly given electoral considerations (...)." For instance, different labour market institutions determine the influence of unions and firms on the level and generosity of unemployment benefits, among other features. Also, different welfare regimes accommodate differently the participation of older workers in the labour market. This situation is associated with ageing and the increase in old age pensions. Older workers may be kept in the labour force through training programs/active labour market policies and/or low public pensions. Additionally, old age pensions legislation varies among welfare states. Some are more influenced by market mechanisms and based on work performance (e.g. liberal); in other cases (e.g. social-democratic) the pension coverage systems are nearly universal, Madero-Cabib et al. (2019). Different welfare models also shape the level and extent of family benefits, since they differ in the relative importance attributed to the state, the market and family for social protection. Nevertheless, a priori it is not clear how each welfare regime mediates the relationship between globalisation and the composition of social expenditure. Kim and Zurlo (2009) identify a negative association between economic globalisation and total social expenditure for the social democratic, conservative and liberal regimes, but only marginal for the latter two. The findings in Leibrecht et al. (2011) suggest that the KOF overall globalisation index presents a negative association with social expenditure in social-democratic and Eastern European countries, a positive association in conservative welfare regimes, while no effect is found for the liberal and southern welfare regimes. Onaran and Boesch (2014) conclude for the existence of positive effects of overall globalisation on social expenditure in the conservative regime, negative effects of overall globalisation in the liberal regime and of overall and economic globalisation in the Baltic countries. Additionally, the authors found no statistically significant effects of overall globalisation in the social-democratic and southern regimes, of economic globalisation in all the former regimes and of both measures of globalisation in the CEENMS regime. Finally, the results in Yay and Aksoy (2018) point to a negative effect of overall globalisation in the liberal regime; of economic globalisation in the liberal and conservative regimes, of political globalisation in the social democratic and liberal regimes and of social globalisation in the conservative regime. The effect is positive for economic globalisation in the social democratic and Mediterranean regimes, for political globalisation in the conservative and Mediterranean regimes but negligibly small, and for the remaining combinations of dimensions of globalisation and welfare regimes no statistically significant effect was found. The former results suggest that there is indeed a mediating role of welfare state regimes that can result in different signed impacts and intensities of the effects of globalisation on social expenditure. However, the welfare regimes and the countries included in each regime do not coincide across studies and this hinders the comparison of the results calling for a more systematic and encompassing approach.

Moving beyond the analysis of the relationship between overall globalisation or economic globalisation alone is important but only Yay and Aksoy (2018) 
disentangle the impact of the three main dimensions of globalisation. Different manifestations of globalisation, including the political and social dimensions, can proceed at different paces with different consequences for the dynamics of social expenditure. Previous studies show that some dimensions of globalisation are indeed more important than others, Meinhard and Potrafke (2012); Haelg et al. (2020). Yay and Aksoy (2018) distinguish between the effects of the economic, political and social dimensions of globalisation across welfare models concluding that the sign of the effects varies with the welfare regime and the specific manifestation of globalisation. For instance, in the Mediterranean regime social expenditure reacts positively to both economic and political globalisation, while social globalisation only influences social expenditure in the conservative model, with a negative sign. For the social democratic, conservative and liberal regimes the impact of the economic and political dimensions of globalisation changes in sign and not always in the same direction. The remaining studies either focus on the economic dimension of globalisation or investigate the impact of the former based on an overall globalisation measure that does not allow to distinguish between the contribution of the social and political dimensions of globalisation relative to the economic one.

From the perspective of the economic outcomes of globalisation (e.g. economic recovery and growth) it is also more informative to look at the composition of social expenditure as different social policies may have variegated economic outcomes, Cammeraat (2020); Crociata et al. (2020); Furceri and Zdzienicka (2012). Kim and Zurlo (2009) is the single study from the ones reviewed in Table 2 that deals with this issue and only for a limited number of social expenditure categories: active and passive labour market spending and social service spending. They conclude that economic globalisation impacts negatively the first two categories of spending and positively the latter, but the type of welfare regime did not mediate the impact of globalisation on any category of spending.

To sum up, limitations of this prior research include differences in the number of welfare regimes and the countries considered in each regime and the measurement and disaggregation of globalisation and social expenditure. Additionally, the econometric approaches applied deal in a limited way with the possibility of reverse causality (applying mostly two-way fixed effects). Our work contributes with comprehensive evidence on the relationship between globalisation and social expenditure by combining data on the most relevant dimensions of globalisation, a wide range of social spending schemes and an established classification of welfare state regimes, together with the application of a robust econometric technique.

\section{Methodology and Data ${ }^{1}$}

We examine whether and how different components of social expenditure are affected by various manifestations of globalisation considering that the link might vary across welfare state regimes. We include also other potential social expenditure

\footnotetext{
1 The presentation in this section follows closely Santos and Simões (2021). They investigate the association between different dimensions of globalisation and varied welfare programs not taking into account the mediating role of welfare models, the focus of the present study.
} 
Table 3 Variables and sources

\begin{tabular}{|c|c|c|}
\hline Variable & Description & Source \\
\hline SocExp & $\begin{array}{l}\text { Public social expenditure as a percentage of } \\
\text { GDP (total and by spending category: old } \\
\text { age, survivors, incapacity-related benefits, } \\
\text { health, family, active labour market policies, } \\
\text { unemployment, housing, other social policy } \\
\text { areas) } \\
\text { Government expenditure on education, total } \\
\text { (\% GDP) from the WDI }\end{array}$ & $\begin{array}{l}\text { OECD Social Expenditures } \\
\text { database } \\
\text { WDI }\end{array}$ \\
\hline$K O F$ & $\begin{array}{l}\text { Overall, economic, social and political glo- } \\
\text { balisation: indices }(0-100)\end{array}$ & KOF (Swiss Economic Institute) \\
\hline gee & $\begin{array}{l}\text { Government effectiveness estimated based on } \\
\text { the perceptions of the quality of public and } \\
\text { civil services and the degree of its independ- } \\
\text { ence from political pressures, the quality } \\
\text { of policy formulation and implementation, } \\
\text { and the credibility of the government's } \\
\text { commitment to such policies. Ranges from } \\
\text { approximately }-2.5 \text { (weak) to } 2.5 \text { (strong) }\end{array}$ & $\begin{array}{l}\text { The Worldwide Governance } \\
\text { Indicators, } 2019\end{array}$ \\
\hline unemprate & $\begin{array}{l}\text { Number of unemployed people as a percent- } \\
\text { age of the labour force }\end{array}$ & $\begin{array}{l}\text { OECD Annual Labour Force } \\
\text { Statistics }\end{array}$ \\
\hline govexp & $\begin{array}{l}\text { General government spending as a percentage } \\
\text { of GDP }\end{array}$ & $\begin{array}{l}\text { OECD Stats } \\
\text { National Accounts }\end{array}$ \\
\hline lpop & Log of total population (thousands of people) & $\begin{array}{l}\text { OECD Stats } \\
\text { Demography }\end{array}$ \\
\hline
\end{tabular}

Source: own elaboration

determinants. We estimate welfare regime-specific globalisation effects based on the regression given by Eq. (1):

$$
\begin{aligned}
\operatorname{SocExp}_{i, t}= & \alpha+\beta_{1} \text { KOF }_{i, t}+\beta_{2} \text { KOF }_{i, t} x \operatorname{Corp}+\beta_{3} \text { KOF }_{i, t} x \text { Lib }+\beta_{4} \text { KOF }_{i, t} x \text { Med } \\
& +\beta_{5} \text { KOF }_{i, t} x C E E C+\beta_{6} \text { KOF }_{i, t} x \text { Others }+\theta^{\prime} Z_{i, t}+\eta_{t}+v_{i}+\varepsilon_{i, t}
\end{aligned}
$$

where SocExp is social expenditure; KOF refers to globalisation; Corp, Lib, Med, $C E E C$ and Others are dummy variables for the different welfare state regimes; $Z$ is a vector of control variables; $\eta_{t}, v_{i}$, and $\varepsilon_{i, t}$, represent the time effects, the country fixed-effects, and the error term, respectively; $i$ identifies the country and $t$ the year. The dataset includes the 36 OECD countries $^{2}$ listed in Table 1 observed over the period 1990-2018. Details on the variables used and respective sources are reported in Table 3.

The composition of social expenditure is accommodated using the nine measures of social expenditure included in the OECD Social Expenditure Database (SOCX): Old age, Survivors, Incapacity-related benefits, Health, Family, Active Labour Market Policies (ALMP), Unemployment, Housing, and Other social policy areas, all

\footnotetext{
2 As of 25 May 2021 the OECD has 38 member countries. Colombia joined the OECD in 2020 and Costa Rica in 2021. We do not analyse these two countries in our dataset due mainly to data constraints.
} 
taken as a percentage of GDP. Additionally, data on government expenditure on education as a percentage of GDP was retrieved from the World Development Indicators (WDI) of the World Bank. Education spending is thus not included in the total public social expenditure variable from OECD SOCX.

Overall globalisation and its dimensions (economic, political, social) are measured using the Swiss Economic Institute (Konjunkturforschungsstelle-KOF) indices of globalisation, Gygli et al. (2019). The KOF overall globalisation index aggregates the information from the three indices on the economic, political and social manifestations of globalisation. The KOF index of economic globalisation includes information on economic flows such as trade, foreign direct investment and portfolio investment and also on restrictions on international trade, investment and capital movements. The KOF index of political globalisation is calculated based on the number of embassies in a country, the number of international organizations to which the country belongs to and the number of international treaties that it has signed, as well as its participation in the missions of the UN Security Council. Finally, the KOF index of social globalisation considers information on personal contacts reflecting linkages between citizens in different countries (e.g. international telephone traffic, information flows, the global dissemination of ideas and cultural proximity).

The mediating role of the different welfare state regimes is analysed through the introduction of interaction terms between the measure of globalisation and a dummy variable representing a specific welfare model. For this purpose we constructed five dummy variables that take the value 1 if a country belongs to a certain regime and 0 otherwise. Corp is a dummy for the conservative or corporatist welfare model; Lib is a dummy for the liberal or Anglo-Saxon welfare model; Med is a dummy for the Mediterranean or Southern European welfare model; CEEC is a dummy for the Central and Eastern European welfare model; Others is a dummy for other welfare models not included in the previous categories. The Nordic/social democratic welfare model is the reference or base group and so does not appear in an interaction term. See Table 1 for the composition of each group. According to Eq. (1), the coefficient $\beta_{1}$ shows the impact of globalisation on the Social Democratic welfare regime, and $\beta_{2}, \beta_{3}, \beta_{4}, \beta_{5}$ and $\beta_{6}$ give the effect of globalisation in Conservative, Liberal, Mediterranean, CEEC and Others welfare regimes, respectively, relative to the impact in the Social Democratic regime. For each of the former regimes, the association between globalisation and social expenditure is measured by the sum of $\beta_{1}$ with the estimated coefficient for the respective interaction term with globalisation, Yay and Aksoy (2018).

The control variables included in vector $Z$ in Eq. (1) were selected based on previous empirical studies, Schulze and Ursprung (1999); Meinhard and Potrafke (2012); Potrafke (2019); Anderson and Obeng (2021); Haelg et al. (2020), but mostly taking into account the studies that deal with the mediating role of welfare models, Kim and Zurlo (2009); Leibrecht et al. (2011); Onaran and Boesch (2014) and Yay and Aksoy (2018). Table 2 identifies the control variables considered in the former studies. Additionally, the need for a parsimonious $\operatorname{model}^{3}$ led us to retain the variables

\footnotetext{
${ }^{3}$ Since we apply a GMM technique that requires that the number of instruments is lower than the number of groups/countries we cannot include in the empirical model a high number of regressors.
} 
that revealed to be statistically significant in a higher number of cases. ${ }^{4}$ Government effectiveness (gee) controls for the effectiveness and efficiency of government's social policies. There is however no consensus in the literature as to the sign of its effect on social expenditure. For instance, Mizrahi (2016) argues for a negative sign since if voters believe that a well-managed government protects equally the standards of living of the whole population, irrespective of the economic status, they will demand less government intervention. Rothstein et al. (2012) and Svallfors (2013), on the contrary, pose that society is more inclined to support welfare policies if there is a sense of fairness and efficiency of public institutions and so the link is positive. As more unemployment is associated with higher demand for social benefits, a higher unemployment rate (unemprate) is expected to pressure social spending up. Spending in social protection and other state functions is likely more important in more interventionist states. To capture the former importance of the public sector we include total public expenditure as a percentage of GDP (govexp) in our regression. A positive relationship with the share of social expenditures is thus expected. Finally, the log of population (lpop) is included to control for country size with a predicted a positive link since e.g. Wagner's law poses that as a country gets richer and population increases public spending tends to rise, Kim et al. (2018); Jibir and Aluthge (2019).

Our dataset corresponds to a balanced panel, i.e. for all the variables we observe each one of the 36 OECD countries in the panel every year from 1990 until 2018. The balanced panel was obtained imputing missing observations, applying the multiple imputation method Amelia II suggested by Honaker et al. (2011). This method assumes a missingness matrix where every single variable included is linearly estimated using the information from all the other variables. This approach applies the EMB algorithm that combines the classic EM algorithm with bootstrap. For more details see Honaker and King (2010). Table 4 contains descriptive statistics for the variables used with the corresponding percentage of missing values that were imputed using the method previously described.

Estimation of Eq. (1) faces a number of problems, in particular the possibility of reverse causality. For instance, social spending can increase the availability and quality of human capital through health and education expenditures, making countries more competitive and leading them to become more globalised. If more globalised countries are also those that experience higher levels of competitiveness, they have the potential to generate more aggregate income and in this way finance higher levels of social spending, Grauwe and Polan (2005); Chen et al. (2014). In this situation globalisation is endogenous in Eq. (1) and correlated with the error term and so common panel data methods such as Pooled OLS, Fixed Effects or Random Effects estimators are biased and inconsistent. In these circumstances, the

\footnotetext{
${ }^{4}$ For instance, we also estimated our model with a proxy for economic growth instead of the unemployment rate. The results for the variables of interest remain basically unchanged but the economic growth variable is not statistically significant in many of the regressions. Since the unemployment rate is negatively correlated with economic growth and is a more encompassing measure that reflects labour market conditions and thus more likely reflects the social vulnerabilities of a country, we kept this variable in our preferred model.
} 
Table 4 Descriptive statistics

\begin{tabular}{lrrrrr}
\hline Variables & Mean & Std. Dev & Min & Max & $\%$ of missingness \\
\hline SocExp_total (\%) & 18.95 & 6.19 & 0.00 & 33.70 & $4.41 \%$ \\
SocExp_old_age (\%) & 6.56 & 2.85 & 0.00 & 14.50 & $6.80 \%$ \\
SocExp_survivors (\%) & 0.92 & 0.75 & 0.00 & 2.88 & $6.80 \%$ \\
SocExp _incapacity (\%) & 2.20 & 1.23 & 0.00 & 5.90 & $6.80 \%$ \\
SocExp_health (\%) & 5.17 & 1.61 & 0.00 & 8.86 & $5.94 \%$ \\
SocExp_family (\%) & 1.92 & 1.00 & 0.00 & 4.39 & $6.80 \%$ \\
SocExp_almp (\%) & 0.51 & 0.44 & 0.00 & 2.68 & $5.94 \%$ \\
SocExp_unemployment (\%) & 0.88 & 0.81 & 0.00 & 4.64 & $9.67 \%$ \\
SocExp_housing (\%) & 0.32 & 0.33 & 0.00 & 1.72 & $10.92 \%$ \\
SocExp_other (\%) & 0.47 & 0.48 & 0.00 & 3.61 & $6.80 \%$ \\
SocExp_education (\%) & 5.15 & 1.22 & 0.00 & 8.56 & $27.49 \%$ \\
KOF_overall (index) & 76.76 & 9.81 & 41.65 & 90.98 & $0.77 \%$ \\
KOF_economic (index) & 70.63 & 12.41 & 33.69 & 92.77 & $0.77 \%$ \\
KOF _social (index) & 76.05 & 10.75 & 38.22 & 92.20 & $0.77 \%$ \\
KOF_political (index) & 83.60 & 13.40 & 25.08 & 98.14 & $0.77 \%$ \\
gee (from -2.5 to+2.5) & 1.30 & 0.57 & -0.26 & 2.35 & $31.03 \%$ \\
unemprate (\%) & 7.76 & 4.03 & 1.66 & 27.49 & $11.59 \%$ \\
govexp (\%) & 44.66 & 7.07 & 22.93 & 65.23 & $31.03 \%$ \\
pop (1000 inhabitants) & 33.07 & 53.85 & 0.25 & 326.84 & $0 \%$ \\
\hline Source: own elabor & & & & & \\
\hline
\end{tabular}

Source: own elaboration

estimation of Eq. (1) may be conducted with instrumental variables methods and a suitable estimator is the Generalized Method of Moments (GMM), Arellano and Bond (1991), and in particular the System GMM estimator, Arellano and Bover (1995); Blundell and Bond (1998), is an appropriate solution. The former provides less biased and more precise results by combining the moment conditions for the model in first differences and for the model in levels. In essence, lags of the levels of variables are used as (internal) instruments for the endogenous variables in the equation in first differences and differences of the variables are used as instruments for the equation in levels. System GMM also allows us to mitigate concerns with measurement error and persistence of the dependent variable. We use an external instrument for globalisation as suggested and used by Lang and Tavares (2018) and Pleninger and Sturm (2020). Assuming that the levels of globalisation of a given country may also be influenced by the levels of globalisation of the neighbouring countries, Lang and Tavares (2018) and Pleninger and Sturm (2020) compute an external instrument for globalisation defined as globalisation's geographically diffusive character. In the same vein, our external instrument for globalisation, $P G$, for country $i$ at time $t$ is computed as the weighed sum of the lagged level of globalisation $\left(K O F_{j, t-1}\right)$ of the remaining OECD countries in our sample, $j$ (with $j \neq i$ ). The weights $\left(\frac{1, t-1}{\text { distance }_{i, j}}\right)$ correspond to the inverse of the population-weighted geographical distance between countries $i$ and $j$, retrieved from Mayer and Zignago (2011). 
The population-weighted geographical distance specifically measures the bilateral distance (using latitudes and longitudes) between two countries weighted by the population share of main agglomerations within those countries. $P G$ is thus calculated as described in Eq. (2):

$$
P G_{i, t}=\frac{\sum_{j \neq i}\left(\frac{1}{\text { distance }_{i, j}} \times K O F_{j, t-1}\right)}{\sum_{j \neq i} \frac{1}{\text { distance }_{i, j}}}
$$

The use of this instrument assumes that the level of globalisation of a given country is positively associated with globalisation in neighbouring countries due to competition, coercion or imitation effects, Anderson and Obeng (2021). To be valid our instrument must not have an effect on social expenditure other than through the level of globalisation of each country (the instrumented variable). Following de Soysa and Vadlamannati (2011), we know of no theoretical or empirical argument linking geographic distance (exogenous) and average globalisation levels in the OECD with the decisions about social expenditure of each individual government. For instance, the level of globalisation in the OECD as a whole and the distance of Austria to other OECD countries should not influence the behaviour of social expenditure in Austria except if they lead to changes in Austria's own globalisation levels, which in turn pressures the Austrian government to change social expenditure. But the latter is precisely the hypothesis we want to test.

The validity of the instruments used in our estimations will be checked using the Hansen test for overidentifying restrictions (null hypothesis is that the instruments are valid). Additionally, following Roodman (2009) we include time dummies to ensure that estimations are not correlated across individuals; we only consider globalisation as endogenous with the remaining variables assumed exogenous; and we perform System-GMM in first differences deviations from a two-step estimate with Windmeijer correction that guarantees more accurate results, Windmeijer (2005).

\section{Results}

We investigate whether the impact of globalisation on social spending differs across the welfare regimes identified in the previous section. To test for the influence of welfare models, we consider the interactions of welfare regimes dummies with globalisation indicators, where the social democratic or Nordic welfare regime is used as the base group and thus no interaction term for this welfare regime is included (see Eq. 1). Table 5 contains the results when considering as dependent variable total public social expenditure and the differentiated effects according to the globalisation variables. Overall globalisation has a statistically significant and positive influence on total social spending in all the welfare state regimes, supporting the compensation hypothesis (column (1)). The welfare model adopted does not seem to mediate the impact of globalisation on such spending since it is identical in all types of welfare state relative to the Nordic model: none of the estimated coefficients 
Table 5 Results with total public social expenditure, overall globalisation and its dimensions

\begin{tabular}{|c|c|c|c|c|}
\hline \multirow[b]{2}{*}{ Variables } & \multicolumn{4}{|c|}{ Dimensions of globalisation } \\
\hline & $\begin{array}{l}\text { (1) } \\
\text { Overall globalisation }\end{array}$ & $\begin{array}{l}\text { (2) } \\
\text { Economic }\end{array}$ & $\begin{array}{l}\text { (3) } \\
\text { Social }\end{array}$ & $\begin{array}{l}\text { (4) } \\
\text { Political }\end{array}$ \\
\hline KOF & $\begin{array}{l}0.329 * * * \\
(0.071)\end{array}$ & $\begin{array}{l}0.252 * * * \\
(0.067)\end{array}$ & $\begin{array}{l}0.287 * * * \\
(0.065)\end{array}$ & $\begin{array}{l}0.306 * * * \\
(0.076)\end{array}$ \\
\hline KOF x Corp & $\begin{array}{l}0.013 \\
(0.041)\end{array}$ & $\begin{array}{l}-0.042 \\
(0.053)\end{array}$ & $\begin{array}{l}-0.024 \\
(0.040)\end{array}$ & $\begin{array}{l}-0.039 \\
(0.059)\end{array}$ \\
\hline KOF x Lib & $\begin{array}{l}-0.020 \\
(0.038)\end{array}$ & $\begin{array}{l}-0.106^{*} \\
(0.055)\end{array}$ & $\begin{array}{l}-0.065 * * \\
(0.032)\end{array}$ & $\begin{array}{l}-0.056 \\
(0.052)\end{array}$ \\
\hline KOF x Med & $\begin{array}{l}-0.016 \\
(0.043)\end{array}$ & $\begin{array}{l}-0.116^{*} \\
(0.062)\end{array}$ & $\begin{array}{l}-0.047 \\
(0.047)\end{array}$ & $\begin{array}{l}-0.057 \\
(0.052)\end{array}$ \\
\hline KOF $x$ CEEC & $\begin{array}{l}-0.052 \\
(0.050)\end{array}$ & $\begin{array}{l}-0.111^{*} \\
(0.061)\end{array}$ & $\begin{array}{l}-0.099 * * \\
(0.049)\end{array}$ & $\begin{array}{l}-0.036 \\
(0.052)\end{array}$ \\
\hline KOF x Other & $\begin{array}{l}-0.102 \\
(0.065)\end{array}$ & $\begin{array}{l}-0.252 * * * \\
(0.075)\end{array}$ & $\begin{array}{l}-0.178^{* * *} \\
(0.065)\end{array}$ & $\begin{array}{l}-0.128^{*} \\
(0.070)\end{array}$ \\
\hline gee & $\begin{array}{l}-1.840 \\
(2.523)\end{array}$ & $\begin{array}{l}-2.723 \\
(2.146)\end{array}$ & $\begin{array}{l}-3.313 \\
(2.315)\end{array}$ & $\begin{array}{l}0.888 \\
(1.656)\end{array}$ \\
\hline unemprate & $\begin{array}{l}0.405 * * * \\
(0.104)\end{array}$ & $\begin{array}{l}0.405^{* * *} \\
(0.100)\end{array}$ & $\begin{array}{l}0.451 * * * \\
(0.111)\end{array}$ & $\begin{array}{l}0.402 * * * \\
(0.091)\end{array}$ \\
\hline govexp & $\begin{array}{l}0.267 * * * \\
(0.092)\end{array}$ & $\begin{array}{l}0.165 \\
(0.105)\end{array}$ & $\begin{array}{l}0.160^{* *} \\
(0.075)\end{array}$ & $\begin{array}{l}0.295^{* * *} \\
(0.102)\end{array}$ \\
\hline Ipop & $\begin{array}{l}-0.869 \\
(1.415)\end{array}$ & $\begin{array}{l}1.816 \\
(1.143)\end{array}$ & $\begin{array}{l}0.465 \\
(0.730)\end{array}$ & $\begin{array}{l}-0.418 \\
(1.257)\end{array}$ \\
\hline Observations & 1044 & 1044 & 1044 & 1044 \\
\hline No. of groups & 36 & 36 & 36 & 36 \\
\hline No. of instruments & 33 & 33 & 33 & 33 \\
\hline p-value for joint F-test & 0.000 & 0.000 & 0.000 & 0.000 \\
\hline $\operatorname{AR}(2)$ p-value & 0.218 & 0.116 & 0.204 & 0.361 \\
\hline Instruments p-value & 0.058 & 0.219 & 0.191 & 0.062 \\
\hline
\end{tabular}

Results with time dummies; standard errors in parenthesis. $* * * ; * * *$ indicate statistical significance at the $1 \%, 5 \%$ and $10 \%$ levels, respectively. The models were estimated assuming globalisation as endogenous and corrected by one strictly exogenous instrument, proximity globalisation (see Sect. 3); SystemGMM was performed in first differences deviations, two-step estimation and with Windmeijer-corrected cluster-robust errors. "AR(2) p-value" is the Arellano-Bond test for autocorrelation's p-value under the null of no second order serial correlation; "Instruments p-value" is the p-value for Hansen test of overidentification under the null of joint validity of the instruments used.

of the five interaction terms is statistically significant. However, our instruments did not pass the Hansen test (the $p$-value indicates rejection of the null hypothesis of joint validity of the instruments used), which suggests we should consider these results only as indicative. Nevertheless, this positive influence is confirmed by all three dimensions of globalisation, columns (2)-(4), and in particular economic and social globalisation for which the validity of our instruments is confirmed (which is not the case for political globalisation). Economic and social globalisation exert a 
positive influence on total social spending, but the impact in almost all the regimes except the conservative regime is lower than in the base group, the Nordic regime. For the Mediterranean regime the impact of social globalisation is the same as that for the Nordic model and for the Others regime the impact of economic globalisation becomes zero and the effect of social globalisation is also quite lower than in the remaining regimes. The political dimension exerts also a positive influence that is the same in all regimes, except in the Others regime for which it is lower. We thus confirm that different welfare models matter for how globalisation influences social expenditure and moreover to the influence of the different manifestations of globalisation. While the sign of the impact of the different dimensions of globalisation is the same across regimes (positive), it is less intense than in the Nordic model (except for the conservative regime) and particularly in the Others regime. Political globalisation exerts the strongest positive influence, followed by social globalisation, while economic globalisation has the smallest impact. This result deserves future investigation especially in the current context when the future of globalisation is being questioned and the possibility that it will not survive COVID-19 discussed, given the necessity to close borders and the reduction in trade flows. The pandemic crisis is slowing the pace of globalisation but it will probably affect in varied ways the different dimensions of globalisation. The result could be a decrease or slowdown in economic globalisation (e.g. through decreased participation in global value chains) and the politics of protectionism and nationalism might reinforce these trends. At the same time more people and firms are connected worldwide, namely online, which increases contacts and the flow of ideas at a global level and increases awareness to what is happening elsewhere. At the political level, the current health crisis is showing that it is crucial to improve global planning, coordinating actions and policy responses, which will conceivably increase political globalisation. According to our results, these different paces of each manifestation of globalisation can have different implications in each type of welfare state.

The results for the control variables confirm theoretical predictions irrespective of the measure of globalisation with estimated coefficients statistically significant at least at the $10 \%$ level. The estimated coefficient for the unemployment rate is always statistically significant and presents the expected positive sign. Higher total public expenditure as a percentage of GDP is an indication of a more interventionist state and so we get a positive coefficient in all the regressions (not significant in column (2)). The estimated coefficient for government effectiveness is in most cases positive but never statistically significant. Bigger countries, with a larger population, are more likely to present a bigger share of social expenditure, which is confirmed by the positive coefficient for lpop in the regressions with economic and social globalisation although not statistically significant. The $p$-values for the autocorrelation (AR2) tests results indicate that it is not possible to reject the null hypothesis of no second order serial correlation.

We next disentangle the effects of globalisation on the dynamics of different components of social expenditure according to the welfare state regime. Table 6 contains a summary of the results for overall globalisation and its different dimensions. Again the social democratic or Nordic welfare regime is used as the base group. The results for the control variables remain basically unchanged relative to the ones 
considering total public social expenditure as the dependent variable, although with some loss of statistical significance. These results are available from the authors.

Analysing the results presented in Table 6 from the perspective of the composition of social spending, for old age pensions (the component representing the highest share of GDP, see Table 4) the impact of overall globalisation is positive and statistically significant, supporting the compensation hypothesis, although smaller in the liberal regime. These results remain basically unchanged for the different dimensions of globalisation, with economic and social globalisation recording a lower positive impact additionally in the Others regime. For survivors pensions there is a positive and statistically significant impact of overall globalisation only in the Mediterranean regime but this effect disappears when considering the three dimensions of globalisation. Incapacity related benefits also do not react to overall globalisation in any of the regimes but in the Mediterranean, CEEC and Others regimes social globalisation pressures this type of spending down, and the same applies to political globalisation in the latter two regimes. Health expenditures, that represent one of the highest shares of total social expenditure are sensitive to globalisation in all the six regimes and with a positive sign, a result associated with all three dimensions of globalisation. Turning to family benefits, overall globalisation has a positive impact on this type of expenditures smaller only in the Mediterranean regime and this is mainly due to social and political globalisation. In the remaining five welfare state regimes globalisation and its manifestations have a positive and similar effect on family benefits. As for expenditure related to the labour market, ALMPs react positively to overall globalisation in the Nordic, conservative and Mediterranean regimes, although the influence is slightly stronger in the first, stemming mostly from political globalisation. Economic globalisation results in a decline in all the regimes except the Nordic, and especially in the CEEC and Others regimes. The latter also applies to social globalisation. Globalisation and its dimensions have no impact on unemployment benefits across regimes, the only exception is a negative impact of economic globalisation in the CEEC regime. Housing expenditures do not react much to globalisation, with a slightly positive impact of all dimensions of globalisation, lower in the conservative, Mediterranean and CEEC regimes (and negative for economic globalisation in the former two regimes), and other social policy areas expenditures are also not affected by globalisation. Finally, education expenditure (one of the three components with the highest GDP shares, see Table 4) reacts positively to overall and economic and social globalisation with the same intensity in all the welfare state regimes, while political globalisation has no impact. Together with the findings for health spending, these results suggest that concerns about international competitiveness are an important determinant of health and education policies as a way to ensure that countries can produce goods and services that are competitive in world markets due to higher productivity of resources and/or better quality (human capital accumulation). The p-values for the Hansen test indicate that it is not possible to reject the null hypothesis of joint validity of the instruments used, except in the regressions with family benefits and overall, social and political globalisation and in the regressions with unemployment benefits and overall and economic globalisation. The former results should thus be interpreted with some caution as far as causality is concerned. 


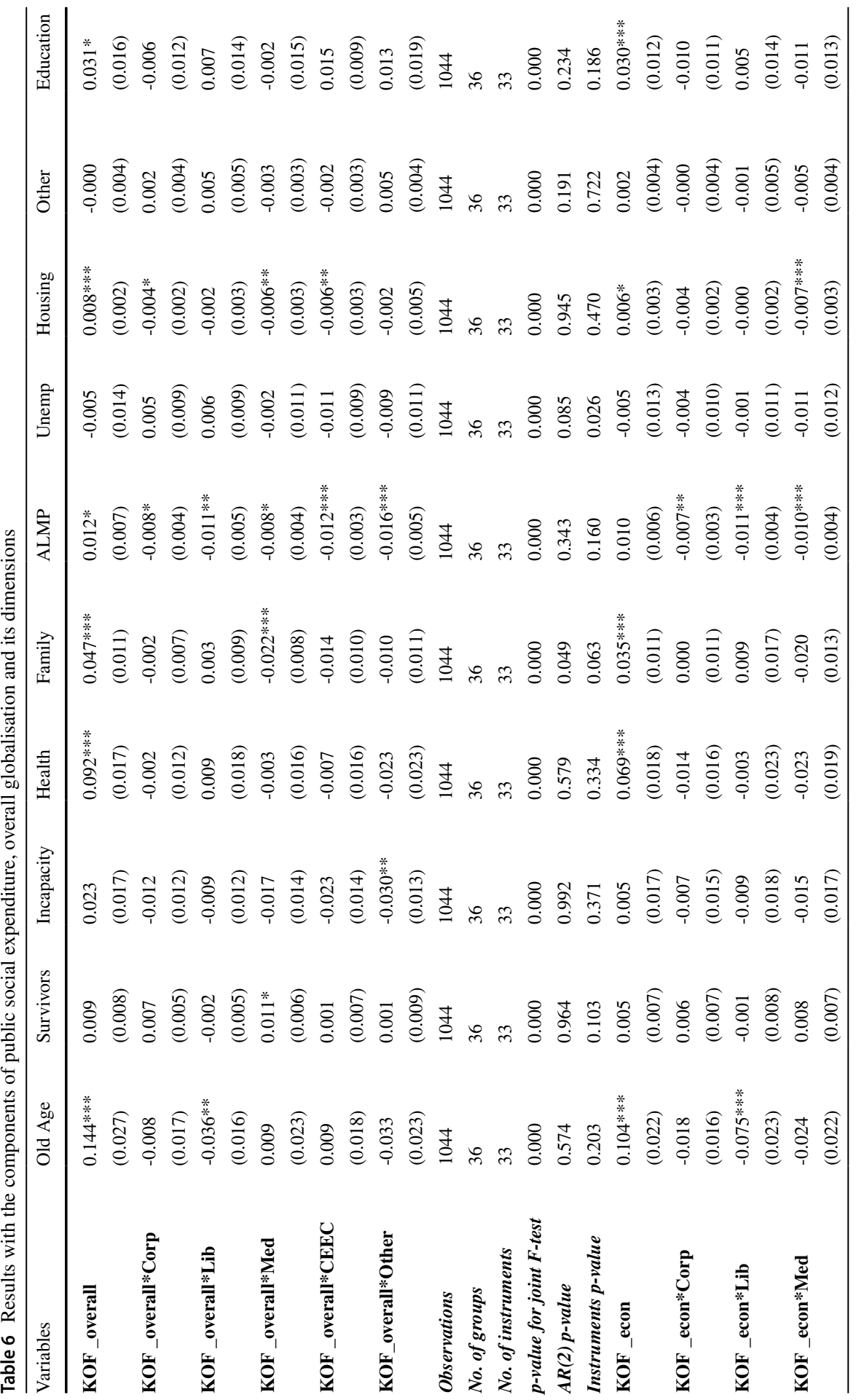




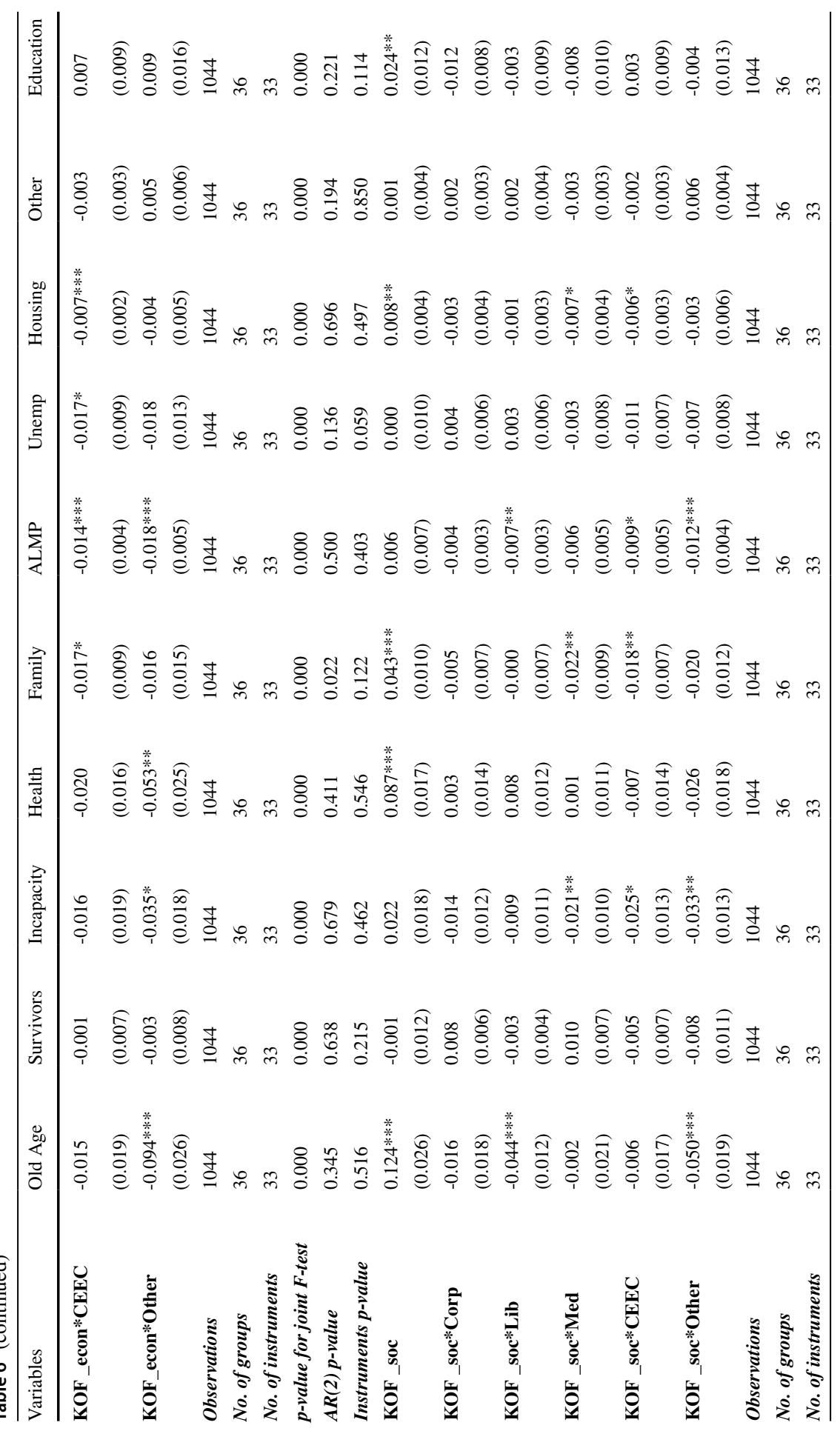




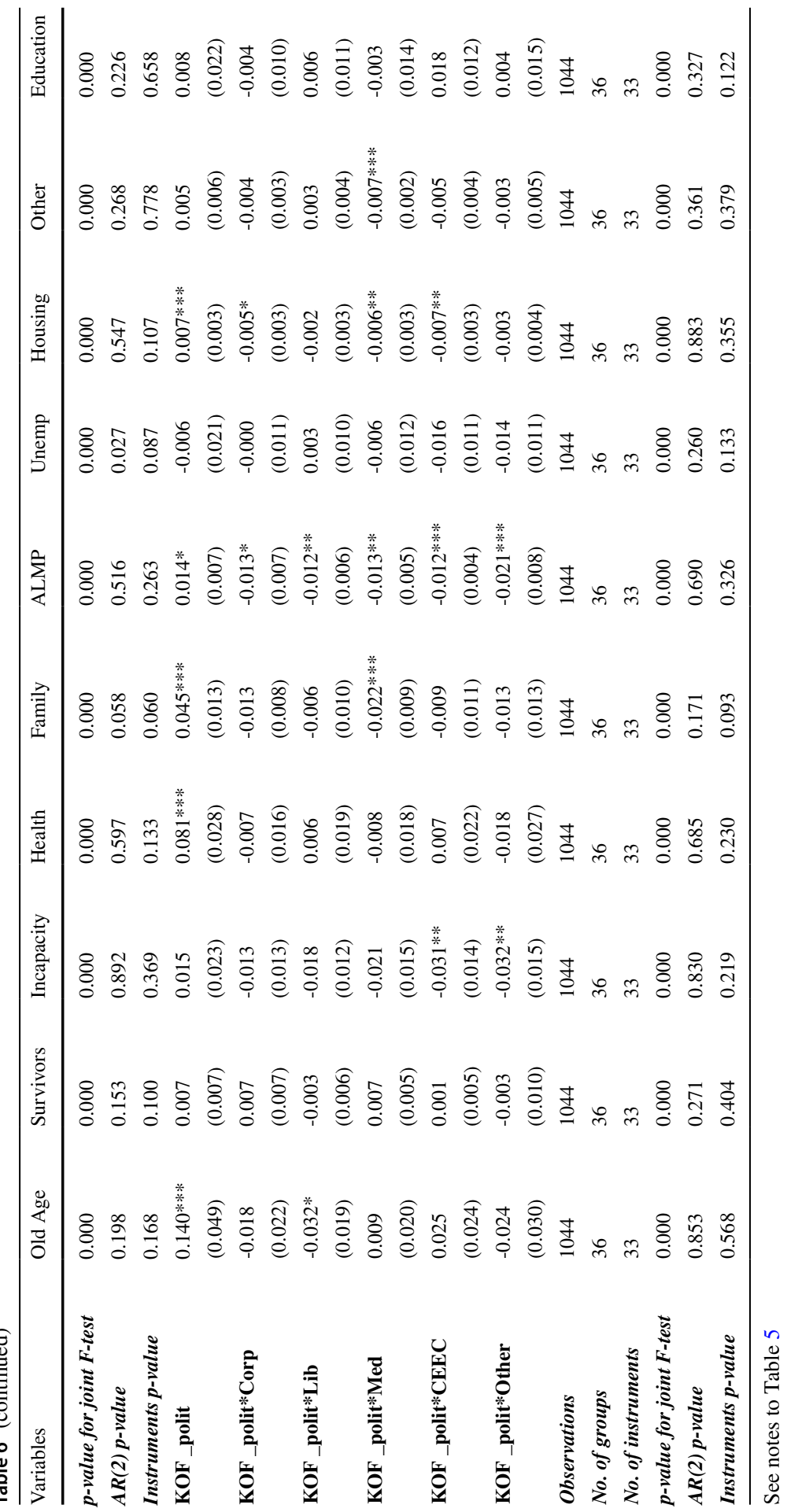


Taking a broad picture, it seems that the reaction of different components of social spending to globalisation is mostly positive (when statistically significant) no matter the welfare regime considered, although the intensity of the effect varies slightly across regimes, usually higher in the Nordic regime. However, four components of social expenditure are not impacted by globalisation, survivors pensions (except for the positive impact in the Mediterranean regime), incapacity and unemployment benefits and other social policy areas. Our results thus do not support the efficiency hypothesis, except for the others regime and ALMPs, which are also negatively affected by economic globalisation in all the regimes except the Nordic. However, our evidence also suggests that the economic outcomes of globalisation might vary across welfare regime since the intensity of the impact (and in some cases the sign) is regime dependent and previous literature as shown that e.g. economic growth and economic recovery respond differently to each component of social expenditure, Cammeraat (2020); Crociata et al. (2020); Schuknecht and Zemanek (2021); Afonso and Jalles (2014); Furceri and Zdzienicka (2012). The previous findings indicate also that the economic and social dimensions of globalisation shape the levels of social expenditure across regimes, although economic globalisation is often identified in the public discourse as the main cause of welfare state retrenchment. The results also point to a positive impact for political globalisation, although our conclusions on causality are uncertain. The results for the different dimensions of globalisation might become particularly important in the wake of the current pandemic crisis, that begs the question of whether COVID-19 means the end of globalisation, or at least a decrease in some of its dimensions. The former will impact differently the composition of social expenditure across welfare regimes and bring about varied economic outcomes of globalisation that can result in divergence of standards of living across countries.

As explained before we analysed the sensitivity of our results to the consideration of other control variables (e.g. real GDP per capita, the growth rate of real GDP per capita, the dependency ratio) that revealed not to be statistically significant in many regressions while in most cases not changing the results for the globalisation variables. Thus they were not included as regressors. We also tested the sensitivity of our findings to the inclusion of the lagged dependent variable as an additional explanatory variable to take into account the persistence of social expenditure, Anderson and Obeng (2021). The results are sensitive to the introduction of lagged social expenditure on the right hand side of our regression confirming the idea that governments cannot change easily expenditure from one year to the next, i.e. the dependence of current social expenditure behaviour on its own past performance, Afonso et al. (2010). This becomes the most important determinant of total social expenditure and most types of social spending, rendering the impact of globalisation statistically insignificant. These results are available from the authors. 


\section{Conclusion}

Theoretical arguments suggest both positive and negative effects of globalisation on social expenditure, implying the issue is essentially empirical. This paper extends the analysis on the link between globalisation and the welfare state by systematically taking into account the mediating role of welfare models on the impact of different dimensions of globalisation on the composition of social expenditure. Using data for 36 OECD countries, this study examines social expenditure responses to rising globalisation over the period 1990-2018 employing panel estimation techniques that account for reverse causality. The established welfare state taxonomy adopted enables a comparative perspective of the interactions between participation in global activities and variegated social policies. The KOF globalisation indices allow the investigation of a variety of channels through which globalisation can affect the dynamics of social expenditure in a country by measuring the globalisation process in its different facets, economic, social and political, highlighting worldwide interactions at the firm and market levels, between citizens from different nations and among governments of varied countries, respectively. The OECD Social Expenditure database allows the study of how the relationship between globalisation and social expenditure differs for nine different types of social spending programs, to which we add education.

The analysis carried out in this study constitutes an initial overview of the possibilities and findings of this more detailed and systematic approach in terms of the interrelations between welfare models, dimensions of globalisation and the composition of social expenditure. The results found suggest that the reaction of different components of social spending is regime specific in terms of intensity but in most cases with a positive sign, supporting in this way the compensation hypothesis. This can shed additional light on the differentiated short and long run economic outcomes of globalisation across regimes, with social expenditure as the channel of influence, an interesting avenue for future research. Different dimensions of globalisation also deliver varied results in terms of the intensity of the respective impact on social expenditure and its composition with economic globalisation reducing ALMPs spending in almost all regimes (the exception is the Nordic regime) and in particular in the others regime. However, for health and education expenditure in particular our findings do not indicate that the differences are regime specific. Globalisation has been investigated mostly in economic terms, but political factors like the participation in international organisations and social globalisation with its higher awareness of the features of welfare regimes in other countries act independently and differently from economic globalisation regarding their influence on the behaviour of social expenditure. The results obtained suggest that the relative pace of change of each manifestation of globalisation may have varied consequences for the development of the welfare state across regimes and consequently on the respective future economic outcomes.

On the whole, globalisation has not undermined the ability of the different welfare state regimes to secure social protection and education, although some categories of social spending record a less positive reaction in specific regimes relative to the Nordic model. Discretionary policy responses to counteract this smaller 
influence could thus be put into place, if these welfare programs are especially relevant to improve the social and economic outcomes of globalisation. At a more general level, given the positive influence of political globalisation on social expenditure, higher coordination of social policy at the OECD level (taking into account the respective composition) as a channel for addressing the negative economic and social consequences of globalisation might help avoiding a relapse into protectionism. From the policy makers perspective, raising the awareness of citizens to the varied social and economic outcomes of specific categories of social expenditure and in this way influence the pressure voters exert regarding changes in social policy could also potentially counteract undesirable consequences of globalisation.

Our approach is limited to the extent that it does not explain the causes of the differences found. In any case, it paves the way for future studies that dig into the whys of the different the results for the dimensions of globalisation and the categories of social expenditure in specific welfare state regimes. Limitations include also the dominant role of persistence in the explanation of the behaviour of social expenditure highlighted by the robustness analysis that included lagged social expenditure as explanatory variable. The health crisis that the world is currently experiencing due to the new SARS-CoV-2 corona virus and the COVID-19 disease has sparked interest in globalisation and social policy. In globalisation because of its potential to curb the increasing integration of world markets, while hopefully strengthening cooperation at the political level. In social policy as a fundamental domain of state intervention to counteract the devastating economic and social consequences of the pandemics. These recent events will probably entail a structural break in the relationship between globalisation and social expenditure that demands additional research as more data becomes available.

Acknowledgements We thank participants at the $22^{\text {nd }}$ INFER Annual Conference, the guest editors of the special issue and two anonymous referees for helpful comments and suggestions.

Funding This research received financial support from COMPETE 2020, Portugal 2020 and the European Union [POCI-01-0145-FEDER-029365]; and from the Fundação para a Ciência e Tecnologia I.P./ MCTES through national funds (PIDDAC) [PTDC/EGE-ECO/29365/2017]. CeBER's research is funded by national funds through FCT - Fundação para a Ciência e a Tecnologia, I.P., Project UIDB/05037/2020.

Data Availability The data that support the findings of this study are available from the corresponding author upon reasonable request.

\section{References}

Afonso A, Agnello L, Furceri D (2010) Fiscal policy responsiveness, persistence, and discretion. Public Choice 145(3):503-530

Afonso A, Jalles JT (2014) Fiscal composition and long-term growth. Appl Econ 46(3):349-358. https:// doi.org/10.1080/00036846.2013.848030

Anderson E, Obeng S (2021) Globalisation and government spending: Evidence for the 'hyperglobalisation' of the 1990s and 2000s. World Econ 44:1144-1176. https://doi.org/10.1111/ twec. 13035

Arellano M, Bond S (1991) Some Tests of Specification for Panel Data: Monte Carlo Evidence and an Application to Employment Equations. Rev Econ Stud 58(2):277-297. https://doi.org/10.2307/2297968 
Arellano M, Bover O (1995) Another look at the instrumental variable estimation of error-components models. J Econom 68(1):29-51. https://doi.org/10.1016/0304-4076(94)01642-D

Aspalter C (2006) The East Asian Welfare Model. Int J Soc Welf 15:290-301

Bergh A, Kärnä A (2020) Globalization and populism in Europe. Public Choice. https://doi.org/10.1007/ s11127-020-00857-8

Blundell R, Bond S (1998) Initial conditions and moment restrictions in dynamic panel data models. J Econom 87(1):115-143. https://doi.org/10.1016/S0304-4076(98)00009-8

Cammeraat E (2020) The relationship between different social expenditure schemes and poverty, inequality and economic growth. Int Soc Secur Rev 73(2):101-123. https://doi.org/10.1111/issr.12236

Chen YF, Görg H, Görlich D, Molana H, Montagna C, Temouri Y (2014) Globalisation and the Future of the Welfare State. IZA Policy Paper No 81

Crociata A, Agovino M, Furia D, Osmi G, Mattoscio N, Cerciello M (2020) Impulse and time persistence of disaggregate welfare expenditure on growth in the EU. Economia Politica 37(1):13-38. https://doi.org/ 10.1007/s40888-019-00156-6

de Soysa I, Vadlamannati KC (2011) Does Being Bound Together Suffocate, or Liberate? The Effects of Economic, Social, and Political Globalization on Human Rights, 1981-2005. Kyklos 64(1):20-53. https://doi.org/10.1111/j.1467-6435.2010.00493.x

Enderwick P, Buckley P (2020) Rising Regionalization: Will the Post-COVID-19 World See a Retreat from Globalization. Transnatl Corp 27(2)

Esping-Andersen GT (1990) The Three Worlds of Welfare Capitalism. Princeton University Press, Princeton, New Jersey

Ferrera M (1996) The "Southern" Model of Welfare in Social Europe. J Eur Soc Policy 6(1):17-37

Furceri D, Zdzienicka A (2012) The Effects of Social Spending on Economic Activity: Empirical Evidence from a Panel of OECD Countries. Fisc Stud 33(1):129-152

Goodman R, Peng I (1996) The East Asian welfare states: Peripatetic learning, adaptive change, and nationbuilding. In: Esping-Andersen G (ed) Welfare states in transition: National adaptations in global economies. Sage, London, pp 192-224

Grauwe P, Polan M (2005) Globalization and Social Spending. Pac Econ Rev 10(1):105-123

Gygli S, Haelg F, Potrafke N, Sturm J-E (2019) The KOF Globalisation Index - revisited. Rev Int Organ. https:// doi.org/10.1007/s11558-019-09344-2

Haelg F, Sturm J-E, Potrafke N (2020) Determinants of social expenditure in OECD countries. KOF Working papers No. $20-475$

Hay C, Wincott D (2012) The Political Economy of European Welfare Capitalism. Palgrave Macmillan, Basingstoke

Heimberger P (2021) Does economic globalization affect government spending? A meta-analysis. Public Choice 187:349-374. https://doi.org/10.1007/s11127-020-00784-8

Hein E, Meloni WP, Tridico P (2021) Welfare models and demand-led growth regimes before and after the financial and economic crisis. Rev Int Polit Econ 28(5):1196-1223. https://doi.org/10.1080/09692290. 2020.1744178

Honaker J, King G (2010) What to Do about Missing Values in Time-Series Cross-Section Data. Am J Pol Sci 54(2):561-581. https://doi.org/10.1111/j.1540-5907.2010.00447.x

Honaker J, King G, Blackwell M (2011) Amelia II: A Program for Missing Data. J Stat Softw 45(7):47. https://doi.org/10.18637/jss.v045.i07

Jibir A, Aluthge C (2019) Modelling the determinants of government expenditure in Nigeria. Cogent Econ Finance 7(1):1620154. https://doi.org/10.1080/23322039.2019.1620154

Kammer A, Niehues J, Peichl A (2012) Welfare regimes and welfare state outcomes in Europe. J Eur Soc Policy 22(5):455-471. https://doi.org/10.1177/0958928712456572

Karamessini M (2008) Continuity and Change in the Southern European Social Model. Int Labour Rev 147:43-70. https://doi.org/10.1111/j.1564-913X.2008.00023.x

Kim D-H, Suen Y-B, Lin S-C, Hsieh J (2018) Government size, government debt and globalization. Appl Econ 50(25):2792-2803. https://doi.org/10.1080/00036846.2017.1409418

Kim TK, Zurlo K (2009) How does economic globalisation affect the welfare state? Focusing on the mediating effect of welfare regimes. Int J Soc Welf 18(2):130-141. https://doi.org/10.1111/j.1468-2397.2008. 00575.x

Koster F (2009) The welfare state and globalisation: down and out or too tough to die? Int J Soc Welf 18:153-162. https://doi.org/10.1111/j.1468-2397.2008.00571.x

Lang VF, Tavares M (2018) The Distribution of Gains from Globalization. IMF Working Papers No. 054 
Leibrecht M, Klien M, Onaran O (2011) Globalization, welfare regimes and social protection expenditures in Western and Eastern European countries. Public Choice 148(3/4):569-594

Madero-Cabib I, Corna L, Baumann I (2019) Aging in Different Welfare Contexts: A Comparative Perspective on Later-Life Employment and Health. J Gerontol B Psychol Sci Soc Sci 75(7):1515-1526. https:// doi.org/10.1093/geronb/gbz037

Mayer T, Zignago S (2011) Notes on CEPII's distances measures: The GeoDist database. CEPII Working Paper 25

Meinhard S, Potrafke N (2012) The Globalization-Welfare State Nexus Reconsidered. Rev Int Econ 20(2):271-287

Mizrahi S (2016) Economic conditions, government effectiveness and public attitudes towards the welfare state. J Poverty Soc Justice 24(2):157-170. https://doi.org/10.1332/175982716X14650295704696

OECD (2019) The OECD SOCX Manual 2019 Edition - A guide to the OECD Social Expenditure Database. OECD, Paris

Onaran Ö, Boesch V (2014) The Effect of Globalization on the Distribution of Taxes and Social Expenditures in Europe: Do Welfare State Regimes Matter? Environment and Planning a: Economy and Space 46(2):373-397. https://doi.org/10.1068/a45370

Onaran Ö, Boesch V, Leibrecht M (2012) How does globalization affect the implicit tax rates on labor income, capital income, and consumption in the European Union? Econ Inq 50(4):880-904. https://doi. org/10.1111/j.1465-7295.2011.00420.x

Pleninger R, Sturm J-E (2020) The effects of economic globalisation and ethnic fractionalisation on redistribution. World Dev 130:104945. https://doi.org/10.1016/j.worlddev.2020.104945

Potrafke N (2015) The Evidence on Globalisation. World Econ 38(3):509-552. https://doi.org/10.1111/twec. 12174

Potrafke N (2019) The globalisation-welfare state nexus: Evidence from Asia. World Econ 42(3):959-974. https://doi.org/10.1111/twec. 12748

Potůček M (2008) Metamorphoses of Welfare States in Central and Eastern Europe. In M. Seeleib-Kaiser (Ed.), Welfare State Transformations 79-95. Basingstoke: Palgrave

Rodrik D (1998) Globalisation, Social Conflict and Economic Growth. The World Economy 21(2):143-158. https://doi.org/10.1111/1467-9701.00124

Roodman D (2009) How to do Xtabond2: An Introduction to Difference and System GMM in Stata. Stand Genomic Sci 9(1):86-136. https://doi.org/10.1177/1536867x0900900106

Rothstein B, Samanni M, Teorell J (2012) Explaining the welfare state: power resources vs. the Quality of Government. Eur Political Sci Rev 4(1):1-28. https://doi.org/10.1017/S1755773911000051

Santos M, Simões M (2021) Dimensions of globalisation and social welfare policies in Organisation for Economic Co-operation and Development countries. J Int Comp Soc 1-16. https://doi.org/10.1017/ics. 2021.4

Schuknecht L, Zemanek H (2021) Public expenditures and the risk of social dominance. Public Choice 188:95-120. https://doi.org/10.1007/s11127-020-00814-5

Schulze GG, Ursprung HW (1999) Globalisation of the Economy and the Nation State. World Economy 22(3):295-352. https://doi.org/10.1111/1467-9701.00205

Svallfors S (2013) Government quality, egalitarianism, and attitudes to taxes and social spending: a European comparison. Eur Polit Sci Rev 5(3):363-380. https://doi.org/10.1017/S175577391200015x

Tridico P, Paternesi Meloni W (2018) Economic growth, welfare models and inequality in the context of globalisation. Econ Labour Relat Rev 29(1):118-139. https://doi.org/10.1177/1035304618758941

Wagener H-U (2002) The Welfare State in Transition Economies and Accession to the EU. West Eur Polit 25(2):152-174. https://doi.org/10.1080/713601579

Weir M (2001) Welfare State. In: Smelser NJ, Baltes PB (eds) International Encyclopedia of the Social \& Behavioral Sciences. Pergamon, Oxford, pp 16432-16435

Windmeijer F (2005) A finite sample correction for the variance of linear efficient two-step GMM estimators. J Econom 126(1):25-51. https://doi.org/10.1016/j.jeconom.2004.02.005

Yay, G. G., \& Aksoy, T. (2018). Globalization and the welfare state. Quality \& Quantity, 52(3), 10151040. https://doi.org/10.1007/s11135-017-0501-z

Publisher's Note Springer Nature remains neutral with regard to jurisdictional claims in published maps and institutional affiliations. 